\title{
Memahami Strategi Komunikasi Pemasaran Kartu Brizzi PT Bank BRI, Tbk. Kanwil Semarang
}

\author{
Widia Febriana \\ (widyafeb2@yahoo.com) \\ (Alumni Ilmu Komunikasi FTIK USM)
}

\begin{abstract}
With increasing public awareness of the technology, there are a trend the demand for banking products based on technology, in particular transactions through cards. But the public's knowledge about the e-money making product marketing e-money is still lacking. To overcome this, we need a marketing communication strategy of e-money is appropriate and effective. The cornerstone of the theory used in this study the theories of Kotler Kotler, said that elements of the promotion mix (promotion mix) consists of five main device, namely: Advertising, Sales Promotions, Public Relations and publicity, Personal Selling and Direct Marketing. This research aims to determine the effectiveness of of the activities of marketing communications strategy that has been done. To analyze the marketing communication strategies, conducted research at PT. Bank Rakyat Indonesia (Persero) Regional Office Semarang. Data collected from various sources consisting of external factors and internal, ie interviews, observation and documentation. Furthermore, these factors were analyzed to get the strategy formulation. Resource persons / informants consists of the CBK offices and the Customer card user Semarang BRIZZI. of all the strategies undertaken in marketing BRIZZI, the most effective way is to give the gift of groceries to customers BRIZZI users when shopping at the supermarkets in Semarang
\end{abstract}

Kata Kunci: Transaksi e-money, Bauran Promosi, Strategi Komunikasi Pemasaran.

\section{Pendahuluan}

Penggunaan uang yang sekarang ini beredar (uang kertas dan uang koin) kini telah bermetamorfosis menjadi uang elektrik yang penggunaannya semakin praktis hanya menggunakan kartu yang salah satu tujuannya adalah mengurangi peredaran uang koin. PT Bank Rakyat Indonesia telah meluncurkan uang elektrik ini yang dinamai Brizzi. Brizzi adalah salah satu jenis produk e-money yang dikeluarkan oleh BRI sebagai pengganti uang tunai untuk melakukan pembayaran. Karena sistem e-money ini baru dan belum semua bank menggunakan, oleh karena itu membutuhkan komunikasi pemasaran yang kongkrit bagaimana langkahlangkah yang diambil dalam memasarkan produk baru e-money ini. Karena BRI sebagai follower sistem $e$ money, maka inilah yang menjadi alasan mengapa pada PT. Bank Rakyat Indonesia penelitian ini dilakukan.

Strategi komunikasi pemasaran adalah suatu perencanaan dan manajemen untuk mencapai tujuan tertentu pada praktik operasionalnya dalam upaya meluaskan pasaran suatu produk, dengan tujuan menciptakan pengetahuan, pengertian, pemahaman, kesadaran, minat dan dukungan dari berbagai pihak untuk memperoleh citra bagi lembaga atau organisasi yang di wakilinya (Kampanye Public Relations, 1997: 37) . Lalu, promosi menjadi bagian dalam salah satu Strategi Pemasaran, dan dalam bauran promosi 
(promotions mix) menurut Kotler (2005: 264-312), mengatakan bahwa unsur bauran promosi (promotion mix) terdiri atas lima perangkat utama, yaitu:

1) Advertising : merupakan semua penyajian non personal, promosi ide-ide, promosi produk atau jasa yang dilakukan sponsor tertentu yang dibayar.

2) Sales Promotion : berbagai insentif jangka pendek untuk mendorong keinginan mencoba atau membeli suatu produk atau jasa.

3) Public relation and publicity : berbagai program untuk mempromosikan dan / atau melindungi citra perusahaan atau produk individualnya.

4) Personal Selling: interaksi langsung dengan calon pembeli atau lebih untuk melakukan suatu presentasi, menjawab langsung dan menerima pesanan.

5) Direct marketing : penggunaan surat, telepon, faksimile, e-mail dan alat penghubung nonpersonal lain untuk berkomunikasi secara langsung, dan mendapatkan tanggapan langsung dari pelanggan tertentu dan calon pelanggan.

Berdasarkan hasil monitoring yang dilakukan oleh Kanwil BRI Semarang, terdapat kelemahankelemahan dalam proses komunikasi pemasaran yang mengakibatkan kurangnya positioning produk dari penggunaan kartu BRIZZI oleh nasabah, yakni dalam mempromosikannya (Advertising, Public relation and publicity dan Personal selling). Oleh karena itu, hal yang menjadi permasalahan adalah bagaimana efektifitas strategi komunikasi pemasaran yang dilakukan oleh Kanwil BRI Semarang dalam memasarkan produk kartu BRIZZI? Tujuan dari studi penelitian ini adalah untuk mendeskripsikan Strategi Promosi kartu BRIZZI pada PT. Bank Rakyat Indonesia Kanwil Semarang.

Berdasarkan tujuan penelitian di atas, dapat diungkapkan bahwa penelitian ini memiliki kegunaan :

a. Secara teoritis, penelitian ini dapat mengkaji teori yang diungkapkan oleh Philip Kotler (1997:228), komunikasi pemasaran terpadu merupakan konsep perencanaan komunikasi pemasaran yang menyadari nilai tambah dari suatu rencana komprehensif yang mengevaluasi peran strategis dari berbagai disiplin komunikasi.

b. Secara praktis, dapat memberikan masukan yang berarti bagi seluruh pihak PT. Bank Rakyat Indonesia Kanwil Semarang dalam meningkatkan eksistensi pemakaian kartu BRIZZI.

\section{Tinjauan Pustaka}

Menurut Duncan (2005:31), Principles of Advertising dan IMC adalah proses perencanaan, pelaksanaan dan pengendalian pesan suatu merk untuk dapat menciptakan hubungan jangka panjang dengan pelanggan, jadi IMC merupakan suatu sinergi, kreatifitas, integrasi dan komunikasi pemasaran terpadu dengan cara memanfaatkan beragam elemen komunikasi yang berbeda-beda agar tercipta koherensi yang saling mendukung (2009: 29)

$$
\text { Menurut Philip Kotler }
$$

(1997:228), komunikasi pemasaran terpadu merupakan konsep perencanaan komunikasi pemasaran yang menyadari nilai tambah dari suatu rencana komprehensif yang mengevaluasi peran strategis dari berbagai disiplin komunikasi misalnya, Faktor-faktor yang mempengaruhi komunikasi yang 
maksimum melalui integrasistrategi pemasaran adalah menyeluruh dari pesan-pesan yang berlainan baik dari 1 . Pemasaran Langsung (Direct Marketing), 2. Promosi Penjualan (Sales Promotion), 3. Hubungan Masyarakat (Public Relations), 4. Penjualan Personal (Personnel selling), 5. Periklanan (Advertising)

Griffin (dalam Ernie Trisnawati, 2008:132) mendefinisikan strategi sebagai rencana komprehensif untuk mencapai suatu tujuan organisasai. Dia juga menjelaskan bahwa strategi tidak hanya sekedar mencapai suatu tujuan akan tetapi strategi juga dimaksudkan untuk mempertahankan suatu organisasi di lingkungan dimana organisasi tersebut menjalankan aktivitasnya.

Untuk mengembangkan strategi pemasaran yang kompetitif, pemasar perlu mengetahui konsumen mana yang cenderung membeli produk-produknya, faktor-faktor apa saja yang membuat mereka menyukai produk kita, kriteria apa yang digunakan untuk memutuskan membeli, dan bagaimana mereka memperoleh informasi mengenai produk kita.

Promosi menjadi bagian dalam salah satu Strategi Pemasaran, dan dalam bauran promosi (promotions mix) menurut Kotler (2005: 264-312), mengatakan bahwa unsur bauran promosi (promotion mix) terdiri atas lima perangkat utama, yaitu:

1) Advertising : merupakan semua penyajian non personal, promosi ide-ide, promosi produk atau jasa yang dilakukan sponsor tertentu yang dibayar.

2) Sales Promotion : berbagai insentif jangka pendek untuk mendorong keinginan mencoba atau membeli suatu produk atau jasa.

3) Public relation and publicity : berbagai program untuk mempromosikan dan / atau melindungi citra perusahaan atau produk individualnya.

4) Personal Selling : Interaksi langsung dengan satu calon pembeli atau lebih untuk melakukan suatu presentasi, menjawab langsung dan menerima pesanan.

5) Direct marketing : penggunaan surat, telepon, faksimil, e-mail dan alat penghubung nonpersonal lain untuk berkomunikasi dengan atau mendapatkan tanggapan langsung dari pelanggan tertentu dan calon pelanggan.

\section{Hasil Dan Pembahasan}

Menurut Onong Uchyana (2004: 29) straategi pada hakekatnya adalah perencanaan (planning) dan managemen untuk mencapai suatu tujuan. Namun untuk mencapai suatu tujuan tersebut, strategi tidak berfugsi sebagai peta jalan yang hanya menunjukan arah jalan saja, namun juga menentukan taktik operasionalnya. Adapun strategi konumikasi menurut Onong merupakan paduan dari perencaan komunikasi (communication planning) dan manajemen komunikasi (communication management) untuk mencapai suatu tujuan (goal).

Setelah melakukan wawancara mendalam peneliti dapat mengungkapkan berbagai hal dan kegiatan tentang strategi komunikas pemasaran kartu BRIZZI yang di lakukan oleh kanwil BRI Semarang, antara lain :

1. Personal selling adalah berbagai inisiatif pesuasif jangka pendek untuk mendorong keinginan pihak ke dua agar mau mencoba atau membeli suatu produk atau jasa. Dalam wawancara, informan menjelaskan bahwa suatu hal wajib bagi semua pekerja di BRI untuk memasarkan BRIZZI kepada 
masyarakat umum, dalam setiap kesempatan, apabila ada costomers yang bertransaksi maka Costumers Service wajib mengedukasi setiap nasabah yang datang, menjelaskan apa itu BRIZZI dan sitem kerja serta manfaat yang didapat.

2. Public Relations yang dimaksud adalah salah satu dari berbagai program dirancang untuk mempromosikan dan untuk melindungi citra perusahaan atau produknya. Program CSR BRI ini di sebut juga dengan BRI PEDULI. Dengan demikian BRI memberikan program CSR atau coorporate sosial responsible kepada masyarakat umum agar mereka aware terhadap perusahaan.

3. Advertising (periklanan) merupakan semua penyajian non personal, promosi, ide-ide, promosi produk atau jasa yang di lakukan sponsor tertentu yang di bayar. Karakteristik iklan adalah bersifat non-personal, komunikasi satu arah, ada sponsor dan bertujuan untuk mengubah sikap dan perilaku seseorang. Biasanya iklan dipakai ketika suatu perusahaa ingin mengubah customers yang tadinya tidak peduli menjadi peduli.

4. Salles Promotions adalah dimana ketika suatu kegiatan yang akan dilakukan membutuhkan dukungan dari suatu produk yang relevan dengan acara yang akan diselenggarakan. Seperti halnya, kegiatan yang dilakukan pada awal tahun 2015 ini, di ADA swalayan pada periode Januari-Maret dengan memberikan promo potongan harga jika melakukan pembayaran memakai BRIZZI.

5. Event Sponsorship, BRIZZI juga biasa mensponsori kegiatan- kegiatan pelajar, seperti basket anatar sekolah. Event sponsoship ini bisa melalui internal maupun eksternal, misalnya jika pihak dari BRI ingin mensponsori suatu kegiatan event yang dilakukan pihak luar ataupun pihak luar ingin eventnya bisa d sponsori oleh BRIZZI. Belum lama ini BRI mengadakan event "BRI Night Run" yang bertempat di simpang lima, disana paa peserta bisa menikmati kuliner khas Semarang dengan membayar memakai kartu BRIZZI dengan harga murah.

Pemasaran adalah suatu kegiatan wajib yang dilakukan oleh seluruh perusahaan untuk mempertahankan kelangsungan hidup perusahaannya, atau dapat pula dikatakan sebagai salah satu cara penyaluran produk barang dan jasa ke tangan konsumen.

Dalam upaya memasarkan produk, perusahaan perlu menjalin komunikasi yang baik dengan konsumen dan perantara melalui komunikasi pemasaran. Seorang pemasar suatu produk harus memahami bagaimana komunikasi itu berlangsung secara umum, suatu model komunikasi pemasaran akan menjawab beberapa hal yang meliputi siapa pengirimnya, apa yang dikatakan (dikirimkan), saluran komunikasi atau media apa yang di gunakan, ditujukan untuk siapa dan apa akibat yang di timbulkan.

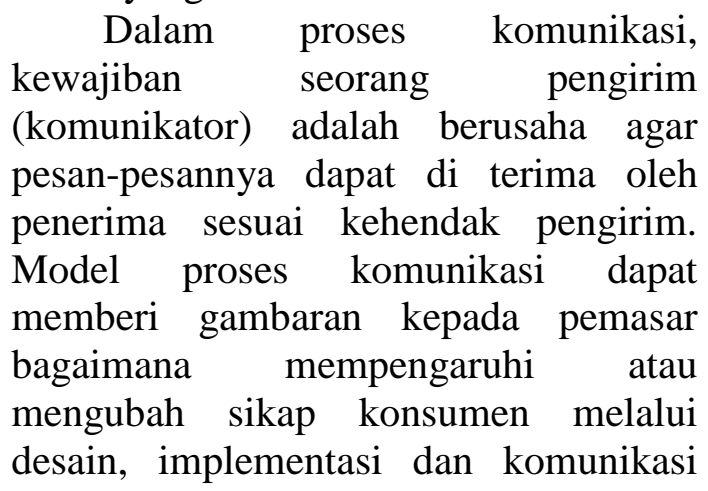


yang bersifat persuasif (Kotler, 2005: 250)

Pada strategi komunikasi peasaran kartu BRIZZI ini, BRI melakukan berbagai strategi yakni, dengan Personal Selling, Public Relations, Advertising, Sales Promotions dan Event Sponsorship. Namun yang paling efektif dari strategi ini adalah dengan Salles Promotion yang memberikan hadiah sembako kepada nasabah yang berbelanja dengan kartu BRIZZI di swalayan yang bekerjasama dengan BRIZZI Bank BRI.

Strategi komunkasi pemasaran yang dilakukan oleh Bank BRI terdiri dari, Personal Selling, Public Relations, Advrtising, Sales Promotions dan Event Sponsorship, oleh karena itu :

1. Personal Selling memiliki efek langsung pada proses penjualan dan keandalan yang paling utama adalah mampu mendekatkan pelaggan dengan penjualan lewat jalur-jalur distribusi barang dan produk yang ada. Lewat personal selling ini pelanggan akan tanpa sungkansungkan menanyakan dn mencari tahu kemampuan produk tersebut dengan leluasa.

2. Public Relations akan membangun efek pemasaran yang sangat lambat sebagai pendukung fungsi-fungsi komuniksi yang lain kepada pelanggan, misalnya perusahaan memberikan bantuan kepada masyarakat sekitar lingkungan perusahaan dengan ikut membantu kesejahteraan mereka dengan kegiatan kemanusiaa dan lain-lain. Membina hubungan baik dan menciptakan hubunga komunitas adalah strategi yang sangat jitu dan baik karena sifatnya yang berkelanjutan bagi perusahaan.

3. Advertising adalah media komuikasi pemasaran yang sudah menjadi bagian integral dari masyarakat dan sistem ekonomi manusia. Beriklan memerlukan metode promosi yang seakurat mungkin karena imbasnya sedemikian dahsyat kepada khalayak, oleh karena itu isi pesan harus dipastikan dapat sampai kepada khalayak sesuai dengan yang perusahaan inginkan.

4. Salles promotions memiliki efek yang singkat sebagai upaya enstimulasi tekanan pada sikap pembelian. Asumsi ini berangkat dari kebiasaan orang yang akan merencanakan sesuatu itu secara mendadak, hal inilah yang akan terjadi pada penjualan lewat sarana ini. Penjualan dalam sarana ini mungkin akan tinggi karena faktor tertentu, bukan pada kesadara pelanggan akan produk tersebut, mereka akan meakai karena kegunaan bukn karena merk yng di tawarkan dalam kmunikasi pemasaran

5. Event Sponsorship suatu sarana dalam pemasaran kounikasi yang memberikan fasilitas dalam menyeponsori suatu kegiatan, kegiatan yang di sponsori haruslah kegiatan yang dapat mewakili produk perusahaan, sehingga tercipta asumsi yang tepat di masyarakat.

\section{Kesimpulan}

Promosi merupakan salah satu strategi dalam memasarkan produk, dalam hal ini produk jasa layanan kartu BRIZZI yang dikeluarkan oleh BRI. Promosi discount di beberapa merchant yang sudah melakukan kerja sama merupakan salah satu strategi komunikasi pemasarang efektif yang diterapkan BRI untuk meningkatkan permintaan BRIZZI. Hal yang tidak kalah pentingnya dalam jasa layanan kartu BRIZZI adalah gaya hidup, dimana pola konsumsi dengan 
menggunakan kartu BRIZZI terlihat ada kaitannya dengan kelas sosial, tingkat penghasilan dan gaya hidup.

Strategi komunikasi pemasaran yang dilakukan oleh Bank BRI terdiri dari, Personal Selling, Public Relations, Advrtising, Sales Promotions dan Event Sponsorship namun, dari ke lima strategi promosi yang ada, salles promotions lah yang paling efektif dalam meningkatkan jumlah pemakai BRIZZI.

\section{DAFTAR PUSTAKA}

Duncan. 2005. Principles of Advertising. Bandung: PT. Bumi Aksara.

Hani Handoko. 1986. Manajemen. Jogjakarta : Balai Pustaka.

Hasibuan, Malayu S.P. 2004. DasarDasar Perbankan. Jakarta: PT. Bumi Aksara.

Info Bank. 2005. Nasabah Mulai Gelisah Survey Loyalitas
Nasabah Bank Umum. Volume xxvii. 36.

Kotler. Philip. 1997. Dasar-dasar Pemasaran. Jilid 1. Jakarta: Prenhallindo

Onong Uchjana Efendi. 2004. Dinamika Komunikasi. PT. Remaja Rosda Karya. Bandung, cet. 6. Bandung.

Rusan Rusady. Kiat dan strategi Kampanye PR. Jakarta : Rosdakarya

www.google.com :

http://www.gweone.com/2014/06/brizzibri-sebagai-uangelektronik.html,4 Agustus 2015

http://www.bank-indo.com/brizzi-uangelektronik-bri/ 4 Agustus 2015

Buku Besar Bank BRI, 2012. Jakarta

Buku Laporan Tahunan BRI, 2012. Jakarta 